\title{
Financial Inclusion and Women's Economic Empowerment in Northern Sri Lanka
}

\author{
Shohani Upeksha Badullahewage \\ Department of Economics \\ Faculty of Humanities and Social Sciences \\ University of Sri Jayewardenepura \\ Gangodawila, Nugegoda, Sri Lanka
}

\begin{abstract}
Most of the women in poor countries are not empowered. Women in these countries are struggling for their household economy. Large part of the world is handling by women. However, the benefits receiving on behalf of their service is very little. When consider about the poverty of women in developing countries it is higher than the poverty of men living in these countries. The empowerment of women is different from one country to another. However, empowerment of women is very important to make them involve in the economy development of a country. When women are empowered their ability on decision making improves. They are able to reach their desired goals. Empowerment of women can improve the economy of a country. The bargaining power and the ability to make the choices in given for the women through the empowerment. Empowerment developed a self-worth within the women. Women gets the ability to control the own life through the empowerment. When consider about the financial inclusion for the empowerment of women it can identify that microfinance is mainly contributing towards the empowerment of women in developing countries. Through microfinance service women get ability to obtain loan.
\end{abstract}

Keywords: Empowerment, microfinance, women

\section{Introduction}

\section{Background of the study}

This study is conducted to examine the role of financial inclusion on the women's economic empowerment in Sri Lanka. Women in most of the developing countries are suffering from the poverty. The main reason for the poverty of women in developing countries is the burning issues in those countries. According to Harper, 1996, women in poor countries are having many disadvantages. There are many reasons for that. However, large part of the work in the world is handling by the women. On behalf of their service, the reward given for them is very little. The rewards in terms of money are very small amount that is receiving by the women. According to World Bank, 2001, there is a slowdown of the growth and slowdown of the national development due to the gender inequality. According to Harper, 1996, the empowerment of women is different from one country to another country. It is because of the income groups living in the countries. However, the economic level of women, social level and the political level of women living in developing countries are very poor. The bargaining power and the ability to make the choices in given for the women through the empowerment. Empowerment developed a self - worth within the women. Women gets the ability to control the own life through the empowerment. Under the communal modern of production women had an equal powerful position or more powerful position than the men. However, the power of the women eventually diminished by the household community.

Sri Lanka faced the terrorist attacks for about thirty years. Therefore, the economy of the country was low down. Mainly the Northern province struggled with the economy. The reason is that the terrorism was highly impact on the Northern province of the country. This study is conducted based on the Kilinochchi district of Sri Lanka. Kilinochchi district is in Northern province. The main income method of people living in Kilinochchi is the agriculture. There are loan facilities available for the rural people living in Kilinochchi district. Laon facilities are given for the people in that area to uplift their living standards. The research study is conducted to identify the empowerment of rural women in Kilinochchi district through the micro credit programs which is a financial aid giving for them to improve their economic level. The research study is conducted to identify the empowerment of rural women in Kilinochchi district through the micro credit programs after the end of war period in Sri Lanka. It is a challenge of empowering the rural women. However, micro credit facility is generating the employment and empowering the economic condition of the rural women. 
From the first chapter of the report it provides the background of the research study. In the second chapter it discusses about the theoretical framework of the research topic. Under the third chapter it discusses about the research method used for the study. Under the fourth chapter data analysis is discussed and final chapter is given the conclusion and the recommendation for the research study.

\section{Literature Review}

\subsection{Introduction}

This section provides a theoretical understanding on the research topic. There are theories described on the financial inclusions, women's empowerment and the support of the financial inclusions on the women's empowerment and the previous researches made on the research topic are described under the literature review.

\subsection{Theoretical framework for women's empowerment through financial services}

According to Harper, 1996, women in poor countries are having many disadvantages. There are many reasons for that. However, large part of the work in the world is handling by the women. On behalf of their service, the reward given for them is very little. The rewards in terms of money are very small amount that is receiving by the women. According to World Bank, 2001, there is a slowdown of the growth and slowdown of the national development due to the gender inequality. According to Harper, 1996, the empowerment of women is different from one country to another country. It is because of the income groups living in the countries. However, the economic level of women, social level and the political level of women living in developing countries are very poor. The bargaining power and the ability to make the choices in given for the women through the empowerment. Empowerment developed a self - worth within the women. Women gets the ability to control the own life through the empowerment. Under the communal modern of production women had an equal powerful position or more powerful position than the men. However, the power of the women eventually diminished by the household community.

Kilinochchi district is situated in the Northern province of Sri Lanka. Mainly there are four administrative divisions for Kilinochchi. There are ninety-five new Grama Officer Divisions in Kilinochchi. The total population in the district according to the estimates is 119,611 . This population includes 30,094 number of non - displaced and there are 89,517 resettled people. Kilinochchi district is an agricultural district in Sri Lanka. It is very famous for the agriculture. There are financial organizations to encourage the people living in the district. There are bank loan facilities available for the people. People can obtain these loan facilities as well as financial facilities to commence businesses, generate income and improve their lives condition. There are foreign aids given for this area since it is a war affected area. The aids are given for the economic development. The rural women of these areas are empowered by the micro credit finance system. however, it is a challenge to empower the rural women. Micro enterprises are helping for the women in rural area to face the challenges. Micro finance enterprises are improving the productivity and the economic level of the women in Sri Lanka.

After the end of the war people in Northern area struggled to improve their living conditions. Microfinance institutions helped them to improve their life conditions. Micro credit was a major instrument to empower the women in Northern area. Micro credit programs are very much supportive in the empowerment of women, specially in the Northern region. Under the MahindaChinthanaya, there was a ten-year plan from 2006 to 2016. Under this plan, they decided to improve the microfinance sector which is helpful for the empowerment of the women's economy in the Northern area. The rehabilitation works were conducted by the government of Sri Lanka after the end of war in 2009. Under the rehabilitation works, microfinance function was developed to give the support for the people living in Northern area. A general belief is that women's access to the credits is resulting for the empowerment of their economy. There are various national and international organizations that are providing the micro finance support for the women by considering their productive role in the development of the economy and the rights of the women. However, there are some questions on the empowering capacity of women by considering the social condition and political condition of the women. (Mayoux, 2002). There is a positive impact from the access to the micro credits. The impact from micro credit is very large for women who are very close to the poverty line. The impact of micro credit increases by increasing the membership period in the microcredit enterprise (Morduch and Haley, 2001). The intensity of loans increased with these factors. Microfinance around the world has developed the economic level of the households. It has been able to enhance the assets of the members. The microfinance able to diversify the occupation among the members. However, there are many issues associate with the empowerment of the women's economy by reducing the capacity of the poverty through the micro credit facility (Skarlatos, 2004).

The first loan that is obtaining through microfinance is very small. Using that loan women cannot make a change in their income which is long lasting. The increase of the assets to the credits is taking place for the second instance. It is in the same geographical area. Therefore, women could provide the products to the market. 
The reason for this is that poor women engage in the similar businesses. Thirdly, the women can successful with the business. However, the success of the business is having the negative impact on the young girls who are going to school. They have to help mother without going to the school. According to Dejene, 2007, the microfinance and other small enterprises are providing the employment for the women who have no any other means of income. Selfemployment is highly ding by the women. However, the small enterprises of women are affecting to reduce the poverty of household. Most of the women are not reaching to the high potential growth. Labor burden, lack of the skills, weak infrastructure, weak businesses, limited environment to engage in the business, lack of financial resources and the limited access to the local market are some of the factors that influence on the women on not reaching to the high potential growth.

Arorar, 2011, stated that women's' empowerment is significantly influencing by the microfinance. The empowerment of women is effectively increasing due to microfinance. Women able to obtain the credit for their housing repairs, for marriage purposes of their children, for the educational purposes and for the purpose of consumption. The main reason for empowerment of economy of women is the good saving habit. However, still there is the lack of the awareness on the microfinance service offering for the women by the banks and financial institutions.

Kabeer, 2005, stated that there are social changes influence on the micro finance organizations to work for the empowerment of the women's economy. Micro finance organizations have implemented the strategies on the poor women who are doing transactions with them. They made the groups for poor. Therefore, poor women get the chance to share their experience with the similar women. Practicing of being in a group is affecting to empower the individual woman and the collective of individuals. There are two social aspects of providing a financial service for women. First is to provide a training to the finance organizational staff. Second is to build up social relations among the groups (Mayoux, 2002). Micro finance is improving the education of the children. Microfinance is giving a great result for women when it compared with the result given for men.

According to Tilakaratne et al., 2005, microfinance in Sri Lanka is very important in empowering the lives of women. The research conducted by Tilakaratne et al., 2005 have identified that most of the women who obtained the support from microfinance have been able to start up their own business. The training provide by the microfinance has been very supportive for them to develop their economic empowerment. According to the gender statics database of World Bank, the unemployment rate of women is higher than the unemployment rate of men. In most of the economies women are paid less and they are belonging to the unorganized informal sector. These statics are very helpful to identify that women should empower with their economy since they are receiving more disadvantages relative to the men (World Bank, 2012). The empowerment of the women and the equality of gender is very important to achieve the security in social, environment, economic and political factors. According to Narayan, 2002, men of the poor countries are dominating the women in the house hold. However, women should provide the access to the credit and participate in the income generation. It can influence on the strategic decision making. Sri Lanka is a developing country. Women living in rural areas of the country has a low living standard. Therefore, micro credits support them to improve their economic level, self-confidence and the knowledge and widen the social network.

The role of micro credit is very much influencing $\mathrm{n}$ the development of the women's economic empowerment. Micro credit is creating the employment for women. Women are given the income opportunities through micro credit. Micro credit empowers women to play an active role in society, in politics and in the economy. Fiancé inclusion is trengthening the women to be secure in the economy.

\section{Methodology}

\subsection{Introduction}

A description on the techniques applying on the overall research to obtain a conclusion on the research topic is describing under the research method. Research method is a most important aspect of the research study. Research method allows the researcher to identify the best technique to implement on collecting data, analyzing data and the arrangement of the data. Research methodology gives a knowledge on various research techniques and the best technique can be chosen for the research study. There are different issues associate with the research study. Use of a proper research methodology can overcome the issues associate with the research study. The research approaches used for the research study and the justifications on the used research techniques are discussed under this chapter. To improve the effectiveness of the research study there are few main factors to be considered under the research method.

\subsection{Research philosophy}

In order to identify a proper research methodology for the research study it is very important to consider about the research philosophy. There is an importance of creating a relationship between the research topic and the knowledge of the data collected during the research study. 
Using the research philosophy, the researcher would able to connect the research topic with the research data collected during the research study. Positivism, interpretive and pragmatism are the main three types of research philosophies mostly considering for the research studies. Under the positivism research philosophy, there are different hypothesis created by concerning the external environment (Tarone et al., 2013). These hypotheses are formed as questions. Under the interpretive hypothesis public partnership is obtained for the research study. Using the public partnership, social and the cultural life is determined. However, interpretive approach is providing a situatable justification for the research subject. It requires to conduct an investigation on the subject matter. Under the pragmatism philosophy actual figures and actual facts are taken into the consideration.

According to the current situation of the report, it has taken the actual facts which are in existence. The analysis of data is done by considering the information collected through trusted sources. Therefore, interpretive philosophy is applied to determine the qualitative outcome of the research study.

\subsection{Research approach}

Conducting a theory for a research study is very useful to obtain a better outcome by conducting the research successfully. The theory which is developed for the research study can be applied for the data collected from various resources. Mainly there are two research approaches that can be used by a research study to obtain an effective outcome. Inductive research approach and deductive research approach are the two main research approaches (Sharp et al., 2002). Collection of data prior to the research topic is doing under the inductive research approach. The opposite of inductive research approach is happening under the deductive research approach. Under the deductive research approach, first the theory is developed. Then the data are collected. After collecting the data and information are obtained, then the theory is developed. After developing the theory, it is applied for the collected information. Under the deductive approach, hypothesis is created. Using the hypothesis, the opinions of people are observed.

In this research study, inductive research approach is applied. Using the inductive research approach, the existing relationship is observed. Explanations relevant to the subject can be developed after observing the subject matter in detail.

\subsection{Research design}

Research design is helpful to integrate various components in an order. Research design is an important element in research methodology. Research design is very important to identify whether the research study has been conducted in an orderly manner. In order to confirm that the research study is conducted orderly by applying the techniques, it is very important to develop a research design. The information related to the research study are addressing under the research design. Descriptive research design, exploratory research design and explanatory research design are the three types of research designs using for the research studies (Nasari, 2011). Answering the questions is easy under the descriptive research design. A detailed discussion on the research question is provided under descriptive research design. Under exploratory research design hypothesis are developed relate to the subject matter. Creation of a cause relationship can be done under the explanatory research design.

Descriptive research design is applied for this research study. The researcher should provide the justifications on various areas of the subject by answering the question. By answering the questions researcher able to obtain better results for the research study.

\subsection{Data collection}

The most important part of the research study is the collection of data. Collection of data relate to the research study cannot be done at the initial stage of the research study. Various methods are used to gather data relate to the research study. After analyzing the data, a reliable result is obtained. Primary data collection method and the secondary data collection method are the main tow types of data collection methods. Under the primary data collection method, data is gathered from the public. Those data have not been used ever before (Kerlinger et al., 2000). Questionnaires, data surveys and interviews are the methods of collecting primary data. Secondary data is collected from the information resources. They have been used before. Therefore, secondary data are not fresh data. Journals, books, newspapers and articles are various sources to collect secondary data.

In this research study, secondary data collection method is used. The information is collected from books, journals, newspapers and articles. The information collected from secondary data are related to the women's economic empowerment and the financial inclusion on the women's economic empowerment. Following sources are used for the research study.

Sarumathi, S. and Mohan, K. (2011), 'Role of micro finance in women's empowerment', An empirical study in Pondicherry region rural SHG's, Journal of Management and Science, Vol.1, No.1, ISSN:2249-1260. 
Rathiranee, Y. and Semasinghe, D.M. (2014), 'Contribution of micro credit program in empowering women: A special preference to Kilinochchi district in Sri Lanka', International Journal of Business and Management Review, Vol.2, No.3, pp.1-16.

Modi, A.G., Patel, K.J. and Patel, K.M., (2014), 'Impact of microfinance service on rural women empowerment: An empirical study', IOSR Journal of Business and Management (IOSR-JBM), Vl.16, pp 68-75, [Online], Available from http://www.iosrjournals.org [Accessed on 29.01.2018].

\subsection{Research technique}

Research techniques help the researcher to conduct the research efficiently and effectively. Researcher can determine to use the quantitative data or qualitative data by considering the research technique using for the research study (Gill et al., 2002). Quantitative data collected can be expressed in numerical form. However, qualitative data cannot be expressed in numerical format. Qualitative data are in descriptive format. Quantitative data are in mathematical format. Quantitative data can be analyzed using statistical tools.

This research study is considering the qualitative data. It is in the descriptive format. Literatures reviewed by different authors are using as qualitative data for the research study.

\subsection{Data analysis}

The output of the research is obtained by analyzing the data collected. This research study is using qualitative data. They are in descriptive form. Therefore, the data analysis is conducting using the descriptive style. In order to make the research study more effective positive impact and the negative impact of information on the research topic is evaluated.

\section{Results and Discussion}

\subsection{Introduction}

Analyzing of data is very important to obtain an effective outcome from the research study. Therefore, data analysis part of this research study is very important. There are data collected through secondary data resources as mentioned in the research methodology. In the data analysis, collected data are presented in an order. The analysis of data is important for deriving a better conclusion for the study. These data are evaluated to obtain a proper outcome. The descriptive style is used for the data analysis. Main reason for that is the use of secondary data. Thematic technique has been used by the research study to analyses the collected secondary data.

\subsection{Research findings}

\section{Theme 1 - Concept of empowerment}

There is an empowerment with human being. People have the capability to raise their lives. They can improve their personal capabilities. There are variety of factors that affect the [personal capabilities. Characteristics of personal and the arrangement of the society are two factors that influence the capability of person. There are most common used dimensions to measure the empowerment of women. There are frameworks to measure the empowerment of women. They have been developed by different authors. Sometimes these frameworks are overlapped. However, economy, culture of the society, families, politics, legal background and psychology affect the empowerment of women. According to the definition of World Bank empowerment is the process of increasing the individual's capacity. This capacity can transform the choices into desired outcomes and actions. Sarumathi and Mohan (2011) stated that the empowerment is the increasing of individual capacity or the capacity of groups in order to make an effective development. Here also it describes that the empowerment can transform the choices into outputs.

\section{Theme 2 - Microfinance}

Microfinance is a strategy that has been implemented to provide the financial service for the rural poor people. Finance service is providing to a group of people. Microfinance is conducting on rural basis. There are groups in villages. They can obtain the loans under small scales. People who do not have the ability to obtain a financial loan from a bank can obtain a loan through microfinance. The rate for the loans is low when compared with the commercial banks. People can choose a payment method according to their possibility. Payment can be done on weekly basis or in monthly basis. Microfinance supports the rural villagers to start their own business, household works or for agricultural works. The impact of micro credit increases by increasing the membership period in the microcredit enterprise (Sarumathi and Mohan, 2011). The intensity of loans increased with these factors. Microfinance around the world has developed the economic level of the households. It has been able to enhance the assets of the members. The microfinance able to diversify the occupation among the members. 


\section{Theme 3 - Microfinance and the empowerment of women}

Most of the microfinance programs are targeting the women and they provide the service to empower the women. There are many motivational actions to empower the women through microfinance. There is an argument that women are included in the majority of poor people in the world. Most of the women are unemployed group in the society. They are underprivileged. Therefore, helping to the women is a priority action of the society. Some others believe that investing on women can give them a chance to have choices and reach for valuable goals in their lives. They can contribute towards the empowerment of the economy of a country. Family well-being increased with the increase of the women's resources. Especially the children well-beingincreased. Greater empowerment can be result from the women's access to the financial services. Therefore, microfinance is acting as a tool to empower the women. Microfinance organizations believe that women are better borrowers. Therefore, more microfinance organizations are establishing to empower the women. Financial services are providing the support by NGO's with a specialized service to improve the empowerment of women. Microfinance has a powerful impact on the empowerment of women.

\section{Theme 4 - Advantages of microfinance on women empowerment}

Kabeer, 2005, stated that there are social changes influence on the micro finance organizations to work for the empowerment of the women's economy. Micro finance organizations have implemented the strategies on the poor women who are doing transactions with them. They made the groups for poor. Therefore, poor women get the chance to share their experience with the similar women. Practicing of being in a group is affecting to empower the individual woman and the collective of individuals. There are two social aspects of providing a financial service for women. First is to provide a training to the finance organizational staff. Second is to build up social relations among the groups (Modi et al., 2014). Micro finance is improving the education of the children. Microfinance is giving a great result for women when it compared with the result given for men. The first loan that is obtaining through microfinance is very small. Using that loan women cannot make a change in their income which is long lasting. The increase of the assets to the credits is taking place for the second instance. It is in the same geographical area. Therefore, women could provide the products to the market. The reason for this is that poor women engage in the similar businesses. Thirdly, the women can successful with the business.

\section{Theme 5 - Women's empowerment through microfinance in Sri Lanka}

There is a positive impact from the access to the micro credits. The impact from micro credit is very large for women who are very close to the poverty line. The impact of micro credit increases by increasing the membership period in the microcredit enterprise (Rathiranee and Semasinghe, 2014). Most of the women who obtained the support from microfinance have been able to start up their own business. The training provide by the microfinance has been very supportive for them to develop their economic empowerment.After the end of the war people in Northern area struggled to improve their living conditions. Microfinance institutions helped them to improve their life conditions. Micro credit was a major instrument to empower the women in Northern area. Micro credit programs are very much supportive in the empowerment of women, especially in the Northern region.Sri Lanka is a developing country. Women living in rural areas of the country has a low living standard. Therefore, micro credits support them to improve their economic level, self-confidence and the knowledge and widen the social network.

\section{Conclusion and Recommendation}

It is very important to consider about the empowerment of women by the state of country. Most of the women in poor countries are not empowered. Women in these countries are struggling for their household economy. Large part of the world is handling by women. However, the benefits receiving on behalf of their service is very little. When consider about the poverty of women in developing countries it is higher than the poverty of men living in these countries. The empowerment of women is different from one country to another. However, empowerment of women is very important to make them involve in the economy development of a country.

When women are empowered their ability on decision making improves. They are able to reach their desired goals. Empowerment of women can improve the economy of a country. The bargaining power and the ability to make the choices in given for the women through the empowerment. Empowerment developed a self - worth within the women. Women gets the ability to control the own life through the empowerment. When consider about the financial inclusion for the empowerment of women it can identify that microfinance is mainly contributing towards the empowerment of women in developing countries. Through microfinance service women get ability to obtain loan. These women who are obtaining loan from the microfinance enterprises do not have the ability to obtain loans from bank. Therefore, microfinance enterprises are giving them loans to pay on weekly or monthly basis. Microfinance loans help women to start their own business. 
At the very beginning the loan obtained through microfinance cannot improve the household economy. However, after becoming an old member of microfinance enterprise women can go for better loans. Then they can invest the money obtained through the loan to a business.

When consider about Sri Lanka, microfinance service can be identified as main finance inclusion contributing towards the empowerment of women' s economy. The research method used for the study able to identify actual data and draw a better conclusion on the research topic.

There are few recommendations that can be made on the financial inclusion for the empowerment of women's economy. It can identify that the microfinance service is the main financial service that empower the economy. It can recommend for banks to start a financing method to empower the women of the nation. The reason is that women are highly contributing towards the economy of a country. Another recommendation is to improve the loan schemes providing for women. There are given to start a self-employment, loan given for the educational purpose of children, loan given to construct the houses. By considering the requirements of women loan schemes can be improved. There is a limitation for the loans giving under microfinance service. This loan amount can be increased considering the present economy, rates and the requirements of women. It can offer special financial services for the women who are successfully paying the loans. This method can motivate other women to join with the microfinance service and empower their economy and life.

\section{References}

Gill, J. and Johnson, P. (2002),Research Methods for Managers, (3rd edn), London: Sage.

Gower. Smith, N.C. and Dainty, P. (1991) The Management Research Handbook, London: Routledge

Kerlinger, F. and Lee, H. (2000),Foundations of Behavioral Research, (4th edn),Fort Worth, TX: Harcourt College Publishers.

Mayoux, L. 1995, Fromvicioustovirtuouscircles? Gender and micro enterprisedevelopment.OccasionalPaper No. 3, UN FourthWorldConference of Women UNRISD, Geneva (May,18, 2005)

Modi, A.G., Patel, K.J. and Patel, K.M., (2014), 'Impact of microfinance service on rural women empowerment: An empirical study', IOSR Journal of Business and Management (IOSR-JBM), Vl.16, pp 68-75, [Online], Available from http://www.iosrjournals.org [Accessed on 29.01.2018].

Narayan, Deepa. (2002). Empowerment and Poverty Reduction. A Source Book, The international Bank for Reconstruction and Development Washington D.C.

Nasri, W., (2011), Factors influencing the adoption of internet banking in Tunisia, International Journal of Business and Management, 6(8), p.143

Rathiranee, Y. and Semasinghe, D.M. (2014), 'Contribution of micro credit program in empowering women: A special preference to Kilinochchi district in Sri Lanka', International Journal of Business and Management Review, Vol.2, No.3, pp.1-16.

Sharp, J., Peters, J. and Howard, K. (2002),The Management of a Student Research Project, (3rd edn),Aldershot:

Skarlatos, k. (2004). Microfinance and Women.sEconomicEmpowerment. Bridgingthe Gap, RedesigningtheFuture. Wisconsin Coordinating Council in Nicaragua. Workingpaper Series No 1.

Sarumathi, S. and Mohan, K. (2011), 'Role of micro finance in women's empowerment', An empirical study in Pondicherry region rural SHG's, Journal of Management and Science, Vol.1, No.1, ISSN:2249-1260.

Tarone, E. E., Gass, S. M. and Cohen, A. D., 2013.Research methodology in second-language acquisition.Routledge.

Tilakaratne, G, Galappattige, A and Perera, R. (2005) PromotingEmpowermentthroughMicrofinance in Sri Lanka, Economic and PoliticalEmpowerment of the Poor (EPEP), Country Studies of Sri Lanka.

World Bank. Original W/Giorgis, EmebetKebede and MelesseDamte. (2005). ViolenceagainstWomen in Addis Ababa. BerchitheannualJouranl of EWLA 2004: Addis Ababa.

World Bank. (2001). Engendering Development: Through Gender Equality in Rights, resources and voice. Summary. Washington D.C.: World Bank. [Online], Available from:http://www.genderstats.worldbank.org [Accessed on 29.01.2018] 